This item was submitted to Loughborough's Research Repository by the author.

Items in Figshare are protected by copyright, with all rights reserved, unless otherwise indicated.

\title{
The face of the nation. Troubling the sameness-strangeness divide in the age of migration
}

\section{PLEASE CITE THE PUBLISHED VERSION}

https://doi.org/10.1111/tran.12236

\section{PUBLISHER}

Wiley (C Royal Geographical Society (with the Institute of British Geographers)

VERSION

AM (Accepted Manuscript)

\section{PUBLISHER STATEMENT}

This is the peer reviewed version of the following article: ANTONSICH, M., 2018. The face of the nation. Troubling the sameness-strangeness divide in the age of migration. Transactions of the Institute of British Geographers, 43(3), pp. 449-461, which has been published in final form at https://doi.org/10.1111/tran.12236. This article may be used for non-commercial purposes in accordance with Wiley Terms and Conditions for Use of Self-Archived Versions

\section{LICENCE}

CC BY-NC-ND 4.0

\section{REPOSITORY RECORD}

Antonsich, Marco. 2018. "The Face of the Nation. Troubling the Sameness-strangeness Divide in the Age of Migration”. Loughborough University. https://hdl.handle.net/2134/28044. 
Forthcoming in Transactions of the Institute of British Geographers, 2018

\title{
The face of the nation.
}

\section{Troubling the sameness-strangeness divide in the age of migration}

\author{
Marco Antonsich \\ Loughborough University
}

\begin{abstract}
Over the last two decades, banal and everyday nationalism have been the main theoretical and methodological approaches for studying how nations are reproduced 'from below'. The present article advances this literature by paying close attention to racially-differentiated subjects and, more precisely, to subjects who are perceived to look different from, but sound like the national majority group. Building on the feminist attention to the corporeal, I argue that face-to-face encounters with the simultaneous embodiment of (somatic) strangeness and (linguistic) sameness generate a sense of surprise which interrupts the reproduction of the nation. This, in turn, allows for the 'troubling' of the very identity category (nation) which both banal and everyday nationalism avoid interrogating directly. I support and illustrate this argument by focusing on the case of the children of migrants born and raised in Italy and their personal experiences in mundane settings. The article discusses the implications of this short circuit in the banal and everyday processes of national reproduction in terms of potential openings of the nation to more inclusive forms.
\end{abstract}

Key-words: strangeness, sameness, nationalism, diversity, Italy

"...and you certainly can't be Italian with that face"

(Mubiayi and Scego 2007, 6) 


\section{Introduction}

Over the last two decades, geographers studying nation and nationalism have largely adopted two main theoretical and methodological frameworks: banal nationalism (Billig 1995) and everyday nationhood (Fox and Miller-Idriss 2008; Brubaker 2006; Edensor 2002). Both approaches originate within the 'cultural turn' which has characterised social sciences more broadly and which, in the case of nationalism, has helped to frame new research questions (Özkirimli 2003). Moving away from the long standing historical tradition of interrogating the 'when' (origin) and 'what' (substance) of a nation, largely dominated by the ethnic/civic debate (Smith 1991), the new scholarship asks 'how' is a nation, i.e. how it works as a practical category for talking, seeing and acting in the world (Brubaker 1994). Given this emphasis on nation as a cognitive medium, it is not surprising that the new approaches share a discursive framework, most notably introduced by Anderson's (1983) highly-celebrated idea of nation as an 'imagined community'. Social interactions among ordinary people in everyday contexts have accordingly become a key site for researching how, but also where and when, the nation becomes a salient category of practice (see, among others, Koch 2016; Antonsich 2016; Skey 2011; Leddy-Owen 2014).

However insightful this scholarship has been, I would argue that the focus on the banal or everyday forms of national reproduction have tended to overlook the conceptual stability of the very term which is reproduced. For instance, in Billig's (1995) Banal Nationalism the focus is on the unconscious flagging of a nation understood as a state-centric construct operating uniformly across space and society. Similarly, Edensor's (2002) engagement with popular culture and the materiality of mundane artefacts, buildings and infrastructures speak of a homogenous nation; however diverse the people and the land-/urban-scapes might be, they all concur with the construction of the nation as an intelligible, familiar, and stable entity. The same logic applies to Fox and Miller-Idriss (2008) who also 
adopt a view 'from below' and make a strong case for nations as practical accomplishments of ordinary people engaging in routine activities. Yet, again, the focus is on the multiple ways people call the nation into existence, rather than unpacking the idea of nation as a differentiated and pluricultural construct.

A possible explanation for this silence regarding the fragmented, interrupted, unstable condition of nation might be related to the fact that they tend to operate with a sort of unencumbered subject, a homo nationalis in Balibar's (1990) primordialist image. True, feminist scholars engaging with banal and everyday nationalism have gendered this subject. They have convincingly scrutinised nationalism as a hetero-male site of power instrumental in reproducing gendered social divisions (McClintock 1995; Anthias and Yuval-Davis 1989; Mayer 2000; Sharp 1996). But, I would propose, their main interest has been to add women to the national picture, giving them agency, rather than questioning the very identity category (nation) which also subsumes women as national bodies. In other words, space has been made for women and, in more recent studies (Puar 2007; Farris 2012), for lesbians and gay men as well in the process of national reproduction, but the identity boundaries of the nation have not been fully explored. Even in the most recent contributions to nationalism informed by a feminist sensibility for emotions and affect (Sumartojo 2016; Militz and Schurr 2016; Closs Stephens 2016; Merriman and Jones 2016), the nation remains unquestioned in its stability as a semantic referent - the focus is on how people 'feel' the nation rather than on the possible plural configurations of nation.

In this article, I use empirical materials collected among Italian children of migrants and their daily 'national' encounters to reflect on the ways their perceived simultaneous (somatic) strangeness and (linguistic) sameness 'trouble' the nation, i.e. call into question its stability as an identity marker. ${ }^{1}$ Taking inspiration from Butler's (1999) critical interrogation of another identity category (gender), my aim is to show how the everyday and the banal are important sites not merely for reproducing the nation, but for questioning its identity boundaries. In this sense, my article offers new insights neither into the notion of 'troubling' nor into the category of gender (which actually did not seem to inflect the encounters 
discussed in the present study). It draws instead on Butler's disruptive intervention on gender to equally interrogate the stability of another identity category, nation. Encountering a 'strange' face which speaks alike disrupts the banal scheme of national reproduction and has the potential to open up the identity category unconsciously or consciously activated in the everyday. The article thus makes a case for expanding the scope of both banal and everyday nationalism and questioning the ethnic by attending to racially-differentiated national subjects and exploring how their perceived simultaneous strangeness and sameness disrupt processes of national reproduction and carry a potential for re-signifying the nation beyond its ethnic character. The focus on Italy is particularly meaningful here, as the fact that the country has experienced a considerable demographic transformation only during the last three decades (Colombo and Sciortino 2004) allows for this strangeness-sameness to be salient in face-to-face encounters.

The article is divided in four parts. In the next section, I discuss the contribution of the literature on banal and everyday nationalism and make the case for putting this literature in conversation with the feminist attention to the corporeal, arguing that different subjects impact differently on and might interrupt the smooth reproduction of the nation as seen in everyday and banal nationalism. I then introduce the case study and illustrate the methodology. In the discussion section, I analyse how faceto-face encounters with strange-same bodies generate a sense of surprise which suspends the takenfor-granted understanding of nation held by the majority group. I then examine the reactions to this surprise as a way to scrutinize possible openings of the nation as an identity category. In the conclusion I reflect on the importance for scholarship on banal and everyday nationalism to attend to raciallydifferentiated bodies in order to better understand processes of national reproduction, but also their limitations and what this means for re-signifying the national mainstream beyond its ethnocentrism. 


\section{Banal and everyday nation}

Both banal nationalism and everyday nationhood are theoretical frameworks which explain how nations are reproduced. When in 1995 Banal Nationalism was published, the major focus of investigation was on the ethnic or civic character of nations (Özkirimli 2003). Briefly put, while the civic nation can be understood as a political-legal community of citizens who share the same civic culture and, therefore, is voluntarist and inclusive, the ethnic nation embodies a community of shared descent, which is ascriptive and exclusive (Smith 1991, 11; Brubaker 1999, 56). Although in time this dichotomy has proved empirically problematic, since all nationalisms present civic and ethnic characters (Yack 1996), it still remain the focus of continuing attention in nationalism studies (Larsen, 2017). Yet, Billig's book asked a different question: once established, how does nationalism reproduce itself? His answer pointed to the unconscious omnipresence of the nation in the landscape ("the flag hanging unnoticed on the public building"), in the words we use (indexical terms such as 'the', 'we', 'here'), in the news we read (organised into domestic and international), or in the weather forecast we watch (nationally bounded). Since then, 'banal' has become a recurrent analytical concept, particularly in geography, for studying how nations are reproduced via objects of everyday use - coins, banknotes, stamps, license plates (Penrose 2011; Raento and Brunn 2005; Unwin and Hewitt 2001; Airriess et al. 2012; Leib 2011).

Closely related to banal, everyday has also emerged as a heuristic device to capture processes of national reproduction 'from below'. The parentage of this notion is more mixed when compared to banal nationalism, as two distinct approaches can be identified. The first originates within geography and refers to the work of Edensor (2002; 2004; 2006). Explicitly taking inspiration from Billig (Edensor $2002,12)$, Edensor explores the material, spatial and performative dimensions of the nation in the everyday. Accordingly, he talks of a nation represented and reproduced in mundane objects (mail boxes, road signs, house styles, street lighting) and in habitual embodied practices (orderly queueing, watching 
the evening show, commuting to work). It is the accumulation of these familiar objects and repetitive actions which draws people and places together into a common spatial and temporal matrix: the nation, indeed.

The second approach to everyday nationhood originates in sociology and takes its lead from Brubaker (2006) and Fox and Miller-Idriss (2008). In this case, the focus is not so much on materiality and routinised and synchronised practices, but on the agency of ordinary people. Contra to Billig's understanding of nation as a constant presence in everyday life, Brubaker $(2006,206)$ maintains that nation is a contingent and contextual discursive resource. It is an intermittent, not a continuous phenomenon, which therefore requires an understanding of when, where, and how it is called into existence during a social interaction. Similarly, Fox and Miller-Idriss $(2008,537)$ argue that a research agenda into everyday nationhood should aim at examining "the actual practices through which ordinary people engage and enact (and ignore and deflect) nationhood and nationalism in the varied contexts of their everyday lives". This is why some scholars have made the case that everyday is a broader notion, which also incorporates the banal (Jones and Merriman 2009), while others have clearly maintained them as two distinct analytical devices (Antonsich 2016).

Whatever the relationship between the banal and the everyday might be, I would argue that both approaches do not fully engage with the socio-demographic differences which make up the national 'we' and with how these differences impact on the reproduction of the nation. Also scholars (Skey 2009) who have aptly criticised Banal Nationalism's for working with an unrealistic notion of a uniform national audience have not further elaborated on what this means for a nation banally reproduced in the everyday. A notable exception comes from feminism, which has openly challenged the notion of an undifferentiated national subject, bringing gender into the picture (McClintock 1995; Anthias and YuvalDavis 1989; Yuval Davis 1997). Feminist authors have contested the gendered identities produced by nationalism qua a male-heterosexual project, which denies agency to women and portrays them, among 
others, as passive biological reproducers or as embodied national boundaries which can be policed (e.g., abortion law) or violated (e.g., war rape) (Dowler and Sharp 2001; Blom et al. 2000; Mayer 2004; Sharp 1996, Mayer 2000). Yet, the main preoccupation of feminist authors has been to broaden the notion of the (geo)political, breaking the public-private divide and making the body a central scale of power dynamics rather than interrogating the internal stability of the nation as a semantic referent. For instance, in the case of Christian et al. (2015), who explicitly read banal nationalism through feminist lenses, one of their main goals is to criticise the opposition between a feminized, emotional and intimate 'banal' and a masculinized, geopolitical and global 'hot' nationalism, without questioning the stability of the nation as an identity marker. Similarly, recent scholarship on affective nationalism (Sumartojo 2016; Militz and Schurr 2016; Merriman and Jones 2016; Closs Stephens 2016) explore how the nation is made present in the everyday life of ordinary people in non-representational ways, unwittingly reproducing mainstreamed versions of national unity rather than exploring its interruptions.

In this article, I wish to build on the feminist attention to the corporeal, but ask a different question. My interest is not so much in how the nation gets differently inflected on different bodies (Radcliffe 1996, 1999; Crang and Tolia-Kelly 2010; Nash 1994), but how different bodies impact on the very identity category of nation. More specifically I am interested in bodies which are perceived to look 'different', but sound 'the same', as is often the case for children of migrants. What happens to banal and everyday processes of national reproduction when strangeness and sameness coexist in the same body? To this end, I believe it is useful to draw on Butler's (1999) notion of troubling. While feminist understandings of nationalism have widely discussed Butler in relation to a gendered and performative nation (Sharp 1996), her key message of 'troubling' the very identity category under discussion (gender for Butler, nation in my case) has not received equal attention. Troubling the nation does not only mean to affirm that national identities are always constructed and under construction (Mayer 2004), but to explore instances in which the reproduction of national identity is interrupted, disoriented and 
potentially subverted. It is an invitation to interrogate the naturalized knowledge associated with nation as an identity category, as well as the categories through which one is 'seen' as national.

In this article, the focus on the corporeal dimension of nationalism (Grabham 2009) privileges a particular feature, the face, as somatic traits were often mentioned by participants in their 'troubled' national encounters. Does the nation have a face? Ahmed $(2000,7)$ has aptly argued that the other is always some-body we 'face', suggesting the importance of a "a visual economy of recognition". Encounters with strangers are always face-to-face encounters (Ibid.). This does not mean, though, that face has a distinct visual logic of recognition compared to let's say skin - the major site of analysis in critical racial studies. Face, I would argue, should instead be understood metonymically, signalling a space where two bodies encounter each other. Like skin, also face stands for a visual signifier of difference, as strangeness is first of all defined in terms of aesthetics of appearance (Ibid., 24, 98 - see also Kristeva 1991, 3-4 for a similar argument). Thus, the enunciative or ontologising power of the visual, i.e. the racializing gaze which fixates some-body in their strangeness (Fanon 1986; Mirzoeff 2011), equally operates on and through the face.

I should say that this article deliberately avoids discussing the rich literature on geographies of encounter (see, among others, Amin 2006; Valentine 2008; Matejskova and Leitner 2011; Wilson 2016) for two main reasons. First, this literature often tends to privilege the local or urban scale at the expense of the national, which is generally portrayed as a site of oppression and discrimination of differences (Antonsich and Matejskova 2015) - a view which would not resonate with the quest of the present article for challenging a racialised understanding of nation. Second, encounters in this literature are conceptualized as generative of a fleeting urban conviviality, which is heralded per se as a model of living with difference. This is not the focus of the present article, which examines instead the discursive role of the nation in preserving togetherness in difference. For these reasons, encounters in this article are operationalized as settings for the study of nation rather than being theorized in their normative 
capacity. Accordingly, in what follows I will analyse banal, everyday face-to-face encounters which have the potential to 'trouble' the nation by generating surprise. As psychologists have observed (Maguire et al. 2011; Foster and Keane 2015), surprise involves the break-down of previously coherent systems of representations and demands a representational updating process. This is indeed what might happen when one faces the co-presence of strangeness and sameness in some-body. The condition of being simultaneously the same but different or in Bhabha's $(1984,126)$ postcolonial notion of mimicry, "a difference that is almost the same, but not quite", operates a disjuncture, a crack in the enunciative or ontologising power of the looking subject (Bhabha 1990; Young 1995). It is exactly on this short-circuit or interruption of the mechanism of national reproduction that my empirical section focuses as a way to problematize existing knowledge on the banal and everyday of the nation.

\section{The Italian context}

Italy has traditionally been a country of emigration. From its political unification in 1870 until 1970, more than 26 million Italians left the country, mainly for the Americas, Australia and other European countries (Gabaccia 2006, 62). Three years later, though, in 1973, an opposite trend started, as for the first time in Italy's history immigrants outnumbered emigrants (Pugliese 2002). Only in the second half of the 1980s, though, would Italy register its first considerable migratory inflow (Zincone 1998). On January $1^{\text {st }}, 2016,5,026,153$ foreign nationals were legally resident in the country or $8.3 \%$ of the total population (ISTAT 2017). Being a relatively recent phenomenon (Colombo and Sciortino 2004), it is not surprising that children of migrants born and bred in Italy have come of age only during the last two decades. Their number is unknown, but on the basis of the latest census data (2011) and other demographic projections, this figure might be between $800,000-900,000$ individuals (AGI 2017). 
Children of migrants have been very active in the public sphere. Numerous associations, with a rich presence on the web and social media, have mushroomed since the early 2000 s both locally and nationally (Andall 2010). Their aims are different. Although a common trait is to work as online forums to share the personal experiences of their members (like in the case of Yallaltalia), some are more active in calling for the reform of the nationality law (Rete G2), others for bridging Italian culture and the culture of their parents (Associna), and others again for creating a space for Islam in Italy (Giovani Musulmani d'Italia). As the Italian nationality law still relies on 'the line of blood' (jus sanguinis), it is not surprising that children of migrants have mobilized politically to exercise pressure on the Parliament to reform this law. ${ }^{2}$ Some have also expressed their claims of belonging to Italy via a variety of artistic mediums: literature, films, and music (Clò 2012; Orton 2012; Russo Bullaro and Benelli 2014; Greene 2012). In all these instances, the common aim is to expand the social boundaries of the nation and make the public aware that children of migrants are not migrants themselves, but offspring of a new, demographically diverse Italy. Writers, in particular, have also tried to rescue the forgotten Italian colonial past (Scego 2015), as a way to show the historical presence in Italy of Somalis and Eritreans, who cannot therefore be equated with more recent migrant populations - a distinction largely ignored or dismissed by the Italian public. This endeavour has also found support and further development among academics, Italian and non, who have introduced postcolonial themes in the debate on Italian identity, aiming at de-constructing narratives of whiteness in the national imaginary (Lombardi-Diop and Romeo 2012). Race, in fact, has been expunged from the debate on the making of the Italian nation, despite having played a key-role, first in the liberal epoch against an internal Other (the Southerner), then, during Fascism, against the colonial Other and the Jews, and more recently against the migrant Other (Giuliani and Lombardi-Diop 2013). Overall, though, the mainstream national discourse continues to be rather oblivious of Italy's colonial past and rather reluctant to engage with issues of race (Petrovich Njegosh and Sacchi 2012). 
Italians' sense of national identity has also been a central topic in academic and public debates (Patriarca 2010; Galli della Loggia 1998; Graziano 2010; Rusconi 1993). Do Italians really share a common identity? Besides the long standing economic divide between the North and the South (Schneider 1998), local identities are also strong (Agnew 2002). Yet, Italians' national pride, according to Eurobarometer surveys, tends to be higher than the EUropean average (Antonsich, 2009) and when it comes to regional or local identities one can also see them as a peculiar way in which a sense of Italianness is articulated rather than contested (Galli della Loggia 1998). Thus, for instance, in relation to language, the use of local dialects do not trump the use of standard Italian - which dates back to the mid-1 $17^{\text {th }}$ century, i.e. before Italian unification (Stergios 2006). On the contrary, the coexistence and mixing of both mediums is actually portrayed as a specific national trait (De Mauro 2017).

Empirical data for the present study come from a larger project which investigates the impact of the demographic change caused by international migration on the idea of nation (http://newitalians.eu/en/). Voices of children of migrants constitute one of the three dimensions analysed (the other two are politico-institutional documentation and views of ordinary people without foreign backgrounds). These voices were collected by focusing on multiple sites. First, we identified their key associations, in terms of national reach and active presence on the web and social media. On this basis, the selected associations were: Rete G2 (http://www.secondegenerazioni.it/), Yallaltalia (http://www.yallaitalia.it/), Associna (http://www.associna.com/it/), and Giovani Musulmani d'Italia (GMI - https://www.facebook.com/GiovaniMusulmanidltaliaGMI/). The main remits of these associations have already been mentioned above. For all of them, we analysed the content (blogs, forums, and videos) posted on the webpages since their creation. Our main interest was in how children of migrants discussed their sense of belonging to Italy, as well as meanings of 'Italy' and 'Italian' and data have been coded accordingly. We also administered 30 semi-structured individual interviews (10 men, 20 women - aged 18-40, median age 29) with some of the most active members of the above 
associations. The interviews shed additional light on the origin, aim, and internal dynamics of the associations and allowed to explore further some of the themes which emerged from the analysis of the web-based data.

In addition, we also conducted an extensive search of the literary, musical and film production of children of migrants, also with the help of secondary sources. We selected those authors who have explicitly addressed themes relevant to the present research and we administered a total of 13 semistructured individual interviews ( 5 women and 8 men, aged 24-48, median age 34): 5 with writers, 3 with film directors, and 5 with rappers (hip-hop is the main musical genre adopted by Italian children of migrants to voice their political claims - Clò 2012). Even in this case, data were coded in relation to how participants discussed their sense of belonging to Italy, as well as meanings of 'Italy' and 'Italian'.

Data were collected with the help of Italian research assistants, whose previous experience of working with children of migrants facilitated the recruitment and interviewing process. All interviews were fully transcribed and to ensure anonymity interviewees were allocated pseudonyms. Literal translations of blog and interview excerpts are from the Author, who is a native Italian speaker.

\section{Nation Interrupted}

I was in Berlin, in front of the famous Wall, when an Italian couple approached me: "Excuse me, could you please take a photo of us?" (in Italian). And I could not resist: "Of course, do you prefer it horizontally or vertically?". "Both thanks!". And while I was taking the photo I heard the girl whispering "Hey... but why this one talks in Italian to us?" 3 
This ironic episode is recounted by Mary Pan on the Yallaltalia blog. Mary was born and raised in Italy to Chinese parents and in time has become quite a popular figure among children of migrants. Besides collaborating with Yallaltalia and Associna, the association of Italians with Chinese background, she has also worked as presenter for a private TV channel (Babel) and as an assistant presenter in a news night show for RAl, the Italian state TV. In the blog entry above, she amusingly comments on the widespread practice of Italian tourists who, being often unable to communicate in foreign languages, "they always and in any case speak Italian wherever they go". The episode is relevant for the level of surprise which generates in the interlocutors. Clearly not expecting that someone with Asian traits could be Italian, the tourist couple approaches Mary with a polite 'scusi' (excuse me), which is the formal and respectful Italian way to address someone unknown. Interestingly, the puzzlement generated by Mary answering fluently in Italian generates a sense of disorientation in the couple. They are unsure of what to make of the situation, which takes place abroad, a context which per se accentuates the distinction between the national 'we' and the others (Skey 2011; Fox 2017). Interestingly, in the ensuing reaction, Mary's social position is suddenly dropped from scusi to questa (this one), i.e. being objectified into an unknown entity that the majoritarian national subject has a hard time to categorise against a nation declined in ethnic terms.

The same experience of surprise is powerfully captured in another anecdote, recalled by Samira, one of our interviewees:

Two weeks ago I went to the crèche where, if all goes well, my son will have to go in September and while I was speaking and explaining to the teacher the character of my son, she got lost and she interrupted me. To say what? "Ah, but you speak Italian so well, they told me at the town council that you were foreigners..." So I asked myself: what did she retain of all my discourse about my son? On what did she concentrate more? On the character of my son or maybe on the fact that 
she was expecting to talk to an immigrant whereas she was speaking to an Italian with the scarf? Because she then totally de-concentrated from my discourse and concentrated instead on the fact that I was speaking Italian well, like her, if not better...

The interviewee is a Muslim young woman, born and raised in Italy to Egyptian parents, and active both in local politics and in the association Giovani Musulmani d'Italia (GMI). In this face-to-face encounter the level of surprise is such that it prevents the conversation from being meaningful, as the teacher is so overwhelmed by the mismatch between what she sees and what she hears that listening cannot take place. Like the previous encounter, this episode also reveals the incongruence between a racialized narrative of nation, which assumes Italian to be exclusively linked to whiteness and Christianity, and a national space which de facto encompasses ethno-racially different people. This incongruence finds an embodied manifestation in the interviewee, who unwittingly generates a 'crisis of reading' (Ahmed 2000,128) in her interlocutor. A face donning a scarf becomes a strange face, out of place in the national imaginary of the Italian teacher, whose surprise exposes and at the same time disrupts Ahmed's $(2000,13)$ visual economy of recognition, where our skins, our faces are supposed to hold 'the truth' of one's (national/racial) identity.

Interestingly, this disruption of a nation reproduced through the banality of supposedly unmarked bodies was also felt in opposite situations, when what was perceived as an Italian face bore instead some foreign markers. Leila (L) and Şirin (S) are two young sisters, born and raised in Italy to Syrian parents, one of them active in the association GMI. During the joint interview, Şirin remarked:

Ş: We don't look Arab, our physiognomy [...] she, even more than me. I as well... but before she started wearing the scarf, you could not... you almost couldn't tell she looked Italian, because she has more Nordic features, hasn't she? Like German, isn't it? Green eyes, clear eyes... 
L: Well, now I put on airs [smiling]

Ş: I mean, sometimes people asked her if she had converted. They always ask. Always. Because... she does not look, I mean they get surprised.

In an interview with another participant, also born and raised in Italy to Syrian parents, a similar occurrence happened:

I am lucky to be Italo-hyphen something, like many others. But I am lucky to have an aspect coherent with my Italian side. What does it mean? It means that my aspect does not conflict with me being Italian in all effect... There are various people like me who are Italo-Cameroonians, ItaloPeruvians, Italo-Chinese who have somatic features which reveal their origin. But since I don't have these somatic features, those people who are a bit slow-witted look at me like a normal person, because it is like this. It happened many times that someone looked at me and told me "Hey, but you look normal". And I replied: "you look normal too". Once it even happened that one with a Moroccan face told me: "but why do you have this name?". "I am of Syrian origins", I replied. "Wow, one cannot see it! How is it possible... you really look normal... you look so normal".

Both excerpts suggest that face comes with a geography. It is what Goldberg (2001, cited in Lombardi-Diop 2011) calls 'geo-phenotypes'. Bodies are mapped onto some specific spaces, often national spaces. Bodies which transgress these borders disrupt people's common-sense knowledge, which assumes a sort of 'somatic norm' (Puwar 2004, 1) attached to nations: "you cannot be Italian with that face" or "you cannot be Syrian with that face". In the case of Italy, the banality of the ethnic nation is also linked to this unspoken somatic norm: a nation made up of a multitude of supposedly unmarked, 'normal', i.e. white faces which concur to the reproduction of a visual national order. Thus, the presence 
of 'normal' faces which also come with foreign features (a scarf, a name) disorients this banal national order; it troubles the nation by breaking down the racialized binary 'we'/'them', opening up the field of possibilities for national belonging.

In the Italian context, where national identity and belonging are often mediated by people's local affiliations, this disruption or disorientation might also manifest in multiscalar terms. The following is an entry on the Rete $\mathrm{G} 2$ blog, followed by a comment by another blogger:

Paduans have a soft tone, compared to the Romans. For me, who I have an oriental face, to shop and go places while 'flaunting' a Roman accent is strange. I don't have other adjectives to describe that feeling of incredulity which I read on the faces of people when I talk to them. When they see me, they think I am Chinese. As soon as I open my mouth, I become Roman. I think people are puzzled. I got used to it in Rome, but here it's like feeling Chinese in Italy and Roman in Padua [...] Kira: OHMYGOOOSH!! I hate when you become a freak show, because you have a foreign face and a vernacular accent. Generally people stop listening, they remain 'mesmerized' by this miracle of nature! ${ }^{4}$

The embodied co-existence of strangeness and sameness makes these children of migrants an "unmanageable and illegible presence", dislocating the assumed ethnic homogeneity of the nation (Queirolo Palmas 2010). In the example above, this dislocation is double, as it calls into existence two spatial registers, the national and the local. In both cases, the enunciative or ontologising power of the visual fixates the identity of the person on the basis of their appearance, but this power is equally disoriented by traits of sameness in that body. This ambivalent presence of an 'outsider-insider' (Bannerji 2000), I would argue, does not only trigger the question 'what are you?'(Paragg 2015), which often people with mixed breeding elicit, but implied in this question is the potential for another identity 
question: 'who are we?'. It forces to reflect on the inner contradictions of a nation defined in ethnoracial terms.

The sense of surprise generated by the co-presence of strangeness and sameness in some-body was a frequent occurrence in the posts and interviews of children of migrants, who also manifested their discontent for the innumerable times they had to explain why this was the case. Like for instance in the following post on Yallaltalia:

Last Saturday, the same $n^{\text {th }}$ question. I go to the transfusion centre for donating blood and, when I am about to finish, a man arrives - I think he was a nurse - who puts me a little plaster. He was already in the room and heard that I was talking [Italian] to the nurse who was taking my blood. I can assure you that my accent has nothing foreign. After putting the plaster he started: "Where are you from?" and I replied: "Do you want to know my origins?" and he: "well, I saw all this hair and [so I thought] you could not be Italian..." and then all the bla bla of compliments, of how well I speak the language, etc. The question does not bother me, but I ask myself: if you hear an unknown and a-bit-coloured person speaking your language without accent, can you not imagine that this person has been living in this country for years and years? Is it so difficult to imagine that before you this question has been already asked ten thousand times and one does no longer want to answer? ${ }^{5}$

Fanon $(1986,23)$ was one the first to highlight the sense of astonishment generated by a racialized body expressing themselves 'properly'. In the excerpt above this feeling is also accompanied, in the child of migrant, by a sense of frustration and an unspoken longing for invisibility. As aptly suggested by Goffman (cited in Queirolo Palmas 2010), the visible, marked body is usually denied a courteous disregard, the right to indifference, or the possibility to go unobserved. This demand of 
invisibility, openly voiced in some interviews and posts, can also be read as a demand of 'normality': a new normal nation, where for instance, as recalled by children of migrants in their personal experiences, they are not asked to act in movies pretending to speak with foreign accents, where they can attend university without always being asked to write a dissertation on their supposed 'country of origin', or where their presence in public offices, banks, or post-offices might be seen as 'normal'. This is indeed the kind of nation children of migrants imagine. Not a civic nation, as there was clear evidence of the importance of the Italian culture (e.g., language, history, traditions, food) in their accounts; but a nation no longer defined in ethno-racial terms. This point is particularly important since, paradoxically, it calls for resuming the banal, everyday nation beyond the troubling caused by their corporeal presence. I will return to this point in the conclusion to reflect on the implications of this paradox for the pluralisation of the nation against the civic/ethnic debate.

\section{After surprise, what?}

The excerpts above illustrate how the nation might be disrupted rather than reproduced in everyday face-to-face encounters. But what is the reaction of the majority society when their taken-forgranted understanding of nation is challenged by some surprising bodies? As mentioned, surprise happens when existing knowledge is no longer able to make sense of what one experiences (Maguire et al. 2011). As the previously coherent representational system breaks down, the subject is therefore called to respond. Below, I will discuss the sense of surprise generated by the co-presence of strangeness and sameness and what this surprise means for re-signifying the nation around a new 'normality', as demanded by the children of migrants. 
From the empirical data, various situations emerge, which at times point to a possible opening of the national identity category and other times confirm its closure. Let me start with an illustration of the first instance:

In the night when Italy's colours shine, an immigrant like many others feels more Italian by lustily cheering the Azzurri [Italian team] ... "World Champions!": here springs the pride of being a naturalized Italian and it does not matter if he is really accepted by the society in which he lives, it does not matter if his appearance is not the one of the average Italian. The young immigrant throws euphorically himself in the crowd for celebrating the victory of his second fatherland. Yes, some incredulous, curious, bewildered party members stare at his almond-shaped eyes. But then the cheering joy triumphs and puts aside prejudices and discrimination. With the help of some national gadgets, bought from a street vendor also foreigner, the young immigrant, who people would call 'second generation', is accepted without too many gazes or inappropriate comments... if only everyday Italy won the world championship! ${ }^{6}$

This episode, posted on the Associna blog when Italy became the football world champion in 2006 , talks of a situation in which the puzzlement generated by a 'strange' face performing national belonging dissolves. Yet, this is not an everyday situation. It is an exceptional context; a situation Skey (2006) would call 'ecstatic nationalism'. In these contexts, as shown by the literature on national atmosphere (Closs Stephens 2016), an overarching feeling of national conviviality, which defies a 'we' vs. 'them' logic, might be generated. The point is obviously how it can be sustained in more mundane, everyday contexts. This seems indeed problematic, as for instance the following extracts illustrate:

A friend of mine came to visit me in Italy and we decided to go to Capri [...]

"Excuse me, where is the port?" 
Five seconds of embarrassing silence, accompanied by a sceptical look.

"Wow, your Italian is so good... but where are you from?

"I am Chinese"

"And why you speak Italian so well?"

"Because I was born here"

"Good, good... You know that your compatriots should do like you? But why they don't learn Italian?!" 7

It is interesting that this post by Mary Pan is titled "Sweet and sour Italy". The episode has indeed an ambiguous, mixed flavour. On the one hand, the surprise triggered by a strange-same face turns into a friendly reception once explained. On the other hand, the distance between the majoritarian national subject and that strange-same face does not go away, as highlighted in the use of 'your compatriots', which keeps Mary and people like her outside the national 'we'.

In other situations narrated by children of migrants, the surprise did not produce any immediate positive reaction at all, as strangeness prevailed over elements of sameness and continued to inform sceptical, if not openly discriminatory attitudes in the observers:

When I was at University, during the lunch break with six other people, I noted a girl who was staring at me and this was annoying. We were talking about various things and one friend asked me if I could pass her my lecture notes. While I was eating my lasagne with great pleasure, the girl who was staring me burst out: "You are foreigner, right?" She does not even give me the time to reply and, without connecting mouth to brain, adds: "But don't you have problems taking lecture notes? And I was also thinking: but how can you like lasagne?" 8 
Here the puzzlement is not resolved, but continues around an escalating scepticism which seems unable to find any acceptable answer. Food - usually a banal marker of national identity (Ichijo and Ranta 2016) - is consciously activated to question the Italianness of a body that does not look Italian and through which, therefore, lasagne cannot go down easily. The banality of the nation works to institute an ontological incompatibility between somatic strangeness and the familiarity of nationally-inflected everyday habits of consumption. The co-presence of sameness and strangeness does not seem to 'trouble' in this case the racialized boundaries of the nation; it fails to open up the field of possibilities for new nation configurations.

Similarly, in the following excerpt, narrated by a Korean man who was adopted at a young age by Italian parents, the surprise does not change the negative attitudes which were triggered in the first instance by aesthetic appearance:

When South Korea won against Italy in the football world cup, suddenly all Asians of my city (Bergamo) became Koreans... I stopped my car at the traffic light, with the window down, and another car with four youngsters on board also stopped. One stared at me and with a mocking smile called the attention of his mates who started insulting me: "Bastard Koreans, get the fuck out of here!", obviously in dialect. Well, I am rather impulsive so I got off, angrily shouting at them also in dialect. They first looked puzzled, but then at the green light they skidded away keep insulting me. ${ }^{9}$

The double layer of national and local identity here returns again to demarcate exclusion. After the initial shock, the group continues in their aggressive otherising practice. Surprise does not produce any immediate change of attitudes, as the sharing of the same vernacular identity is trumped by an understanding of national belonging in terms of somatic sameness. 
In another interesting episode, recounted again by Mary Pan on the Yalla blog, the reaction to the surprise generated by a 'strange' face is also negative, but here the power dynamic between the authority of the majoritarian national subject who fixates the strangeness of some-body and the resistance to this objectification emerge more clearly:

I was at Fiumicino airport [Rome], waiting to fly to Shanghai. There was the queue for the EU nationals and the queue for all the other poor devils. I get into the noble queue and the police officer behind the glass glanced at me in an unfriendly way. In front of me, just one person, whereas dozens people are in the other queue. His colleague in the booth, where the poor devils were standing, tells him: "Look at that one, she thinks she can jump the queue!". I show my passport to the officer, he checks it and gives it back to me. His stupid colleague says: "What?! Have you let her go like this?!". He replies: "She has an Italian passport". She looks at me. I look at her. She lowers her eyes. Finally, she shut up. ${ }^{10}$

Empowered by legal (citizenship) rather than somatic sameness, Mary resists the power of the majoritarian national subject which acts as both an institutional (being a border officer) and a symbolic (belonging to the majority group) gatekeeper of the nation. Mary 'returns the gaze', according to a wellknown form of resistance among racialized subjects (Bannerji 1993). Her counter-gaze is successful, as the majoritarian national subject is defeated in its authority of policing the legal-symbolic boundaries of the nation. For a moment, it seems as if the civic nation could trump the ethnic nation. Yet, one can also read a potential resentment in that lowering of the eyes - a feeling of aggrieved powerlessness in the face of an unexpected or unwanted change of 'their' nation. If so, even in this case surprise might not be transformative. 
In all these instances, surprise is responded to by those who experience it; yet, the potential opening generated by the disruption of familiar knowledge does necessarily lead to an (immediate) change in attitudes. After the brief moment of disruption, in most cases the nation resumes its exclusive thrust, imbued with a racialized visual economy of recognition.

\section{Conclusion}

Scholarship on banal and everyday nationalism has been very effective in showing how the nation is reproduced 'from below', in the unremarkable materiality of the landscape, in the unconscious use of indexical words, or in everyday social interactions. This scholarship, though, seems to have been more preoccupied with the modalities of this reproduction than with what is actually reproduced. Nation in other words has somewhat been taken for granted in its semantic stability. This article has shifted the debate away from the reproduction of the nation to explore instead its interruptions as a way to interrogate possible openings in that semantic stability. When subjects who look 'different', but sound 'the same' are faced by national white subjects a short circuit is generated in the banal and everyday reproduction of the nation. The sense of dis-orientation, puzzlement and displacement felt in these encounters 'troubles' the taken-for-grantedness of the nation in its racialized essence.

In a recent article, Fox (2017) has focused on similar break-downs in the banal reproduction of the nation. Using Garkinkel's (1967) notion of background expectancies, Fox explores in depth the 'repair work' needed to restore a familiar understanding of nation when it is 'breached' by unexpected situations. My argument, however, is that breaching should be explored for its potential to open up rather than restore the mainstream which has been breached. Surprise in fact carries a transformative potential which might re-write the identity category, transgressing its boundaries towards a more inclusive 'horizon' (Fortier 2008). 
This potential, however, does not come without limitations. Findings of the present study suggest two points worthy of consideration. First, since strange-same encounters failed to clearly produce the expected transformation among white majority individuals, it is legitimate to caution against investing the everyday with too much transformative power. This was also the original recommendation of Amin (2002: 976) in his study of the everyday in the multicultural city, highlighting the importance of national public culture in informing practices of local conviviality. Change in the ways boundaries of national belonging are drawn cannot only spur from occasional face-to-face encounters, as these would always remain contextual and contingent occurrences (Matejskova and Leitner 2011). Thus, the micro of the everyday should be read in connection with the macro of societal and institutional structures (e.g., citizenship regimes, mainstream narratives in the media, physical presence of 'strange faces' in public roles), as the latter condition the categories and meanings which can be deployed in everyday social interactions (Hearn and Antonsich, 2016). A change in these macro structures would possibly generate a new visual economy of recognition, as new categories through which one could 'see' the nation become available. This is not to suggest that a transformation in the racialized nation might only be possible 'topdown', but to invite students of everyday and banal nationalism to explore further the links between the micro and the macro of the nation in order to detect when and which openings are possible.

Second, the troubling of the nation produced by strange-same encounters seems to find a limitation in the demand of 'normality' voiced by the children of migrants. Two considerations ensue from this point. First, troubling the semantic stability of the nation does not necessarily imply troubling its unifying thrust. Contrary to some influential postcolonial literature which maintains "the impossible unity of the nation as a symbolic force" (Bhabha 1990, 1), the present study reveals that, from the perspective of the racialized Other, the nation might be no less a unifying socio-spatial register than for the majority society. Children of migrants did not question the role of the nation in bringing diverse people together, including themselves. For them the nation remains an important cognitive, symbolic 
and emotional register; and, importantly, a cultural register too. In fact, there is no clear evidence in the data collected that points to a demand for rewriting the nation in civic terms - a solution often portrayed by critical race scholars as a way out of the 'ethnic absolutism' which is seen to characterise the nation (Gilroy 1987). What children of migrants questioned were the racialized boundaries of the nation more than its cultural boundaries, which they also contribute to reproduce in their everyday practices. In this sense, everyday nationalism allows to go beyond the 'civic' vs 'ethnic' debate and rejoins other scholars who have called for a third, distinct dimension: cultural nationalism (Nielsen 1996, Woods 2014).

This leads to the second consideration. Children of migrants qua racialized subjects are not only a locus of resistance against a nation irremediably imbricated with race (Gilroy 1987, Balibar and Wallerstein 1991, Jackson and Penrose 1993). By conflating nationalism with racism and making the limits of race coincide with the national limits (Gilroy 1987, 46), this view risks casting them as permanently outside the nation and denies them agency in processes of national reproduction. It is not surprising that various scholars working on diversity issues, including geographers (see, for instance, Ehrkamp 2005, Leitner and Ehrkamp 2006, Koefoed and Simonsen 2011), have moved away from the nation as a site intrinsically ridden with discrimination and exclusion and focused instead on alternative socio-spatial registers (often the transnational and the urban) where diversity is said to feel more at home. Forms of identity politics which coalesce, for instance, around the Black transnational diaspora (see Andall 2000 for the Italian case) similarly speak of this move away from and beyond the nation. Yet, the faces of children of migrants are equally part of the nation like the majority white faces, which often entitle themselves with an exclusive power to decide on whom belongs to the nation (Hage 2000, Nayak 2017). More importantly, they equally contribute to the reproduction of the cultural nation in their everyday life. This is why it is important for banal and everyday nationalism to unpack more convincingly 
the national public along racial and ethnic lines (as well as other intersectional axes), as a way to map the variable geometry of the identity boundaries of the nation which would be otherwise assumed to be reproduced uniformly and homogenously across an undifferentiated (often white) public. In an epoch of resurgent white, populist nationalism (Brubaker 2017), 'troubling' the nation in this way seems a rather timely and important task.

\section{Acknowledgments}

The data collection would have not been possible without the help of Silvia Camilotti, Lorenzo Mari, Stefano Pasta, Valeria Pecorelli, and Sonia Pozzi. Thank you to Sarah Holloway, Michael Skey and three anonymous reviewers for their valuable comments. This work was supported by the European Commission under Grant PCIG13-GA-2013-618470.

\section{References}

AGI 2017 Lo 'ius soli' darebbe la cittadinanza a un milione di minori stranieri. Agenzia Giornalistica Italiana.http://www.agi.it/factchecking/2017/02/23/news/ius_soli_legge_stranieri_migranti_cit tadinanza-1524349/

Agnew J A 2002 Place and Politics in Modern Italy University of Chicago Press, Chicago.

Ahmed S 2000 Strange encounters Routledge, London.

Airriess C, Hawkins M, and Vaughan E 2012 Situating banal nationalism, the culture wars, and civil religion: governing localized geographies of national identity in Indiana Social \& Cultural Geography 13 49-67.

Amin A 2002 Ethnicity and the multicultural city: living with diversity Environment and planning A 34 959-980. 
Amin A 2006 The good city Urban Studies 43, 1009-1023.

Andall J 2002 Second-generation attitude? African-Italians in Milan Journal of ethnic and migration studies 28, 389-407.

Andall J 2010 The G2 network and other second-generation voices in Andall J and Duncan D eds, National Belongings, Peter Lang, Bern 171-194.

Anderson B 1983 Imagined Communities Verso, London.

Anthias F and Yuval-Davis N 1989 Woman-nation-state Springer, New York.

Antonsich M 2016 The 'everyday'of banal nationalism - Ordinary people's views on Italy and Italian Political Geography 54, 32-42.

Antonsich M and Matejskova T 2015 Immigration societies and the question of 'the National' Ethnicities $15,495-508$.

Balibar E 1990 The nation form: history and ideology Review, 329-361.

Balibar E and Wallerstein I 1991 Race, nation, class Verso, London.

Bannerji H 1993 Returning the gaze Sister Vision Press, Toronto.

Bannerji H 2000 The dark side of the nation Canadian Scholars' Press, Toronto.

Bhabha H 1984 Of mimicry and man October 28, 125-133.

Bhabha H 1990 Nation and narration Routledge, London.

Billig M 1995 Banal Nationalism Sage, Thousand Oaks, CA.

Blom I, Hagemann K, and Hall C 2000 Gendered nations Berg Oxford.

Brubaker R 1994 Rethinking Nationhood: Nation as Institutionalized Form, Practical Category, Contingent Event Contention 4, 3-14.

Brubaker R 1999 The Manichean myth: Rethinking the distinction between 'civic'and 'ethnic'nationalism in Kriesi H. et al. (ed) Nation and national identity Zürich Rügger 55-71. 
Brubaker R 2006 Nationalist politics and everyday ethnicity in a Transylvanian town Princeton University Press, Princeton.

Brubaker R 2017 Between nationalism and civilizationism: the European populist moment in comparative perspective Ethnic and Racial Studies 40, 1191-1226.

Butler J 1999 Gender Trouble Routledge, London.

Christian J, Dowler L, and Cuomo D 2015 Fear, feminist geopolitics and the hot and banal. Political Geography 54, 64-72.

Clò C 2012 Hip Hop Italian Style. The Postcolonial Imagination of Second-Generation Authors in Italy in Lombardi-Diop C. and Romeo C eds Postcolonial Italy Palgrave, New York 275-291.

Closs Stephens A 2016 The affective atmospheres of nationalism cultural geographies 23, 181-198.

Colombo A and Sciortino G 2004 Gli immigrati in Italia il Mulino, Bologna.

Colombo E 2010 Figli di migranti in Italia UTET, Torino.

Crang M and Tolia-Kelly D P 2010 Nation, race, and affect: senses and sensibilities at national heritage sites Environment and Planning A 42, 2315-2331.

De Mauro T 2003 Storia linguistica del'Italia unita Laterza, Roma-Bari.

Dowler L and Sharp J 2001 A feminist geopolitics? Space and Polity, 5, 165-176.

Edensor T 2002 National identity, popular culture and everyday life Oxford, Berg.

Edensor T 2004 Automobility and National Identity: Representation, Geography and Driving Practice Theory, Culture \& Society 21, 101-120.

Edensor 2006 Reconsidering national temporalities. Institutional times, everyday routines, serial spaces and synchronicities European Journal of Social Theory 9, 525-545.

Ehrkamp P 2005 Placing identities: Transnational practices and local attachments of Turkish immigrants in Germany Journal of Ethnic and Migration Studies 31, 345-364.

Fanon F 1986 Black skin, white masks Pluto Press, London. 
Farris S R 2012 Femonationalism and the" Regular" Army of Labor Called Migrant Women History of the Present 2, 184-199.

Fortier A-M 2008 Multicultural horizons Routledge, New York.

Foster M I and Keane M T 2015 Why some surprises are more surprising than others Cognitive psychology 81, 74-116.

Fox J E 2017 The edges of the nation: a research agenda for uncovering the taken-for-granted foundations of everyday nationhood Nations and Nationalism 23, 26-47.

Fox J E and Miller-Idriss C 2008 Everyday nationhood Ethnicities 8, 536-563.

Gabaccia D R 2006 Razza, nazione, trattino in Guglielmo J and Salerno S eds Gli italiani sono bianchi? il Saggiatore, Milan 61-78.

Galli della Loggia E 1998 L'identità italiana il Mulino, Bologna.

Garfinkel H 1967 Studies in ethnomethodology Polity Press, Cambridge.

Gilroy P 1987 There ain't no black in the Union Jack Routledge London.

Giuliani G and Lombardi-Diop C 2013 Bianco e nero Mondadori, MIlan.

Grabham E 2009 Flagging'the Skin: Corporeal Nationalism and the Properties of Belonging Body \& Society $15,63-82$.

Graziano M 2010 The failure of Italian nationhood Palgrave, London.

Greene S 2012 Equivocal Subjects Bloomsbury, New York.

Hage G 2000 White nation Routledge, London.

Hearn J and Antonsich M 2016 Theoretical and methodological considerations for the study of banal and everyday nationalism. International workshop Breaching banal nationalism, Antwerp University, 27-28 May.

Ichijo A and Ranta R 2016 Food, National Identity and Nationalism Palgrave, Basingstoke.

ISTAT 2017 Demografia in cifre ISTAT, Rome. 
Jackson P and Penrose J eds 1993 Constructions of race, place, and nation UCL Press, London.

Jones R and Merriman P 2009 Hot, banal and everyday nationalism: Bilingual road signs in Wales. Political Geography 28, 164-173.

Koch N 2016 Is nationalism just for nationals? Civic nationalism for noncitizens and celebrating National Day in Qatar and the UAE Political Geography 54, 43-53.

Koefoed L and Simonsen K 2011 'The stranger', the city and the nation: on the possibilities of identification and belonging European Urban and Regional Studies 18, 343-357.

Kristeva J 1991 Strangers to ourselves Columbia University Press, New York.

Larsen CA 2017 Revitalizing the 'civic'and 'ethnic'distinction Nations and Nationalism 23, 970-993.

Leddy-Owen C 2014 'I had a hard time actually trying to catch the essence of Englishness’ Social \& Cultural Geography 15, 747-768.

Leib J 2011 Identity, banal nationalism, contestation, and North American license plates Geographical Review 101, 37-52.

Leitner H and Ehrkamp P 2006 Transnationalism and migrants' imaginings of citizenship Environment and Planning A 38, 1615-1632.

Lombardi-Diop C 2011 Spotless Italy: Hygiene, Domesticity, and the Ubiquity of Whiteness in Fascist and Postwar Consumer Culture. California Italian Studies 2, 1-22.

Lombardi-Diop C and Romeo C 2012 Postcolonial Italy Palgrave, Basingstoke.

Maguire R, Maguire P and M T Keane 2011 Making sense of surprise: an investigation of the factors influencing surprise judgments Journal of Experimental Psychology 37, 176-186.

Matejskova T and Leitner H 2011 Urban encounters with difference: The contact hypothesis and immigrant integration projects in eastern Berlin Social \& Cultural Geography 12, 717-741.

Mayer T 2000 Gender Ironies of Nationalism in Mayer T ed Gender Ironies of Nationalism Routledge, London 1-22. 
Mayer T 2004 Embodied Nationalism in Staeheli L A, Kofman E and Peake L eds Mapping Women, Making Politics Routledge, London 153-167.

McClintock A 1995 Imperial leather Routledge, London.

Merriman P and Jones R 2016 Nations, materialities and affects Progress in Human Geography, doi:

$10.1177 / 0309132516649453$

Militz E and Schurr C 2016 Affective nationalism: Banalities of belonging in Azerbaijan Political

Geography 54, 54-63.

Mirzoeff N 2011 The right to look Critical Inquiry 37, 473-496.

Mubiayi I and Scego I 2007 Quando nasci è una roulette Terre di Mezzo, Milan.

Nash C 1994 Remapping the body/land in Blunt A and Rose G eds Writing women and space Guilford

Press, New York 227-250.

Nayak A 2017 Purging the nation: race, conviviality and embodied encounters in the lives of British

Bangladeshi Muslim young women Transactions of the Institute of British Geographers doi:10.1111/tran.12168.

Nielsen K 1996 Cultural nationalism, neither ethnic nor civic. Philosophical forum 28 42-52

Orton M 2012 Writing the Nation: Migration Literature and National Identity Italian Culture 30, 21-37.

Özkirimli U 2003. Nationalism and its Futures Palgrave, London.

Paragg J 2015 'What are you?': Mixed race responses to the racial gaze Ethnicities, https://doi.org/10.1177/1468796815621938.

Patriarca S 2010 Italian Vices Cambridge University Press, Cambridge.

Penrose J 2011 Designing the nation. Banknotes, banal nationalism and alternative conceptions of the state Political Geography 30, 429-440.

Petrovich Njegosh T and Sacchi A 2012 Parlare di razza ombre corte, Verona.

Puar J K 2007 Terrorist assemblages Duke University Press, Durham. 
Pugliese E 2002 L'Italia tra migrazioni internazionali e migrazioni interne il Mulino, Bologna.

Puwar N 2004 Space invaders Berg, Oxford.

Queirolo Palmas L 2010 Within, against, beyond the Colour-line. Darkmatter, 6.

Radcliffe S A 1996 Gendered Nations: Nostalgia, development and territory in Ecuador Gender, Place and Culture 3, 5-22.

Radcliffe S A 1999 Embodying national identities: Mestizo men and white women in Ecuadorian racialnational imaginaries Transactions of the Institute of British Geographers 24, 213-225.

Raento P and Brunn S D 2005 Visualizing Finland: Postage stamps as political messengers. Geografiska Annaler B 87, 145-164.

Rusconi E 1993 Se cessiamo di essere una nazione il Mulino, Bologna.

Russo Bullaro G and Benelli E 2014 Shifting and shaping a national identity. Troubador publishing, Kibworth Beauchamp.

Scego I 2015 Adua Giunti, Florence.

Schneider J 1998 Italy's 'Southern Question' Berg, Oxford.

Sharp J R 1996 Gendering nationhood. A feminist engagement with national identity in Duncan B ed Bodyspace Routledge, London 97-107.

Skey M 2006 'Carnivals of Surplus Emotion?' Towards an Understanding of the Significance of Ecstatic Nationalism in a Globalising World Studies in Ethnicity and Nationalism 6, 143-161.

Skey M 2009 The national in everyday life: A critical engagement with Michael Billig's thesis of Banal Nationalism The Sociological Review 57, 331-346.

Skey M 2010 'A sense of where you belong in the world': national belonging, ontological security and the status of the ethnic majority in England Nations and Nationalism 16, 715-733.

Skey M 2011 National belonging and everyday life Palgrave Macmillan, Basingstoke.

Smith AD 1991 National Identity Penguin, London. 
Stergios J 2006 Language and nationalism in Italy Nations and Nationalism 12, 15-33.

Sumartojo S 2016 Commemorative atmospheres: memorial sites, collective events and the experience of national identity Transactions of the Institute of British Geographers 41, 541-553.

Unwin T and Hewitt V 2001 Banknotes and national identity in central and eastern Europe Political Geography 20, 1005-1028.

Valentine G 2008 Living with difference: reflections on geographies of encounter Progress in Human Geography 32, 323-337.

Wilson H F 2016 On geography and encounter Bodies, borders, and difference Progress in Human Geography doi 10.1177/0309132516645958

Woods E 2014 Cultural nationalism Studies on National Movements, 2, http://roar.uel.ac.uk/4165/1/51151-1-PB.pdf

Yack B 1996 The myth of the civic nation Critical Review 10 193-211.

Young R J 1995 Colonial desire Routledge, London.

Yuval Davis N 1997 Gender \& Nation Sage, London.

Zincone G 1998 Illegality, enlightenment and ambiguity: A hot Italian recipe South European Society and Politics 3, 45-82.

\footnotetext{
${ }^{1}$ The term 'children of migrants' in this study does not refer to under-age persons, but to individuals aged 18 or above, born and raised in Italy to foreign immigrant parents. As for the terms 'sameness'/'strangeness', I should specify that I treat them as categories of practice, i.e. categories called into existence by the respondents and whose meanings cannot be defined a priori but it is context-dependent.

${ }^{2} \mathrm{~A}$ reform of the nationality law which facilitates the acquisition of citizenship for children of migrants born in Italy or, if born abroad, who have spent a school cycle in Italy was approved by the Lower House in 2015 and is now pending in the Upper House. Rete G2 has played a key role in lobbying the Parliament for this change to be possible (http://www.secondegenerazioni.it/g2-parlamenta/).

${ }^{3}$ Yallaltalia, blog post 17/09/2013: http://www.yallaitalia.it/2013/07/guarda-che-ti-capisco-il-bello-di-esserestranieri/

${ }^{4}$ Rete G2, blog post 15/11/2006: http://www.secondegenerazioni.it/2006/11/15/un-g2-romano-a-padova/

${ }^{5}$ Yallaltalia, 04/01/2013 comment to post http://www.yallaitalia.it/2013/01/immigrati-per-forza-o-per-scelta/

${ }^{6}$ Associna, blog post 11/07/2006: http://www.associna.com/it/2006/07/11/il-racconto-di-un-immigrato-in-cimaal-mondo/
} 
${ }^{7}$ Yallaltalia, blog post 26/02/2013: http://www.yallaitalia.it/2013/02/litalia-tinta-di-agrodolce/

${ }^{8}$ Rete G2, blog post 27/01/2009: http://www.secondegenerazioni.it/forum/viewtopic.php?f=22\&t=1739

${ }^{9}$ Rete G2, blog post 01/09/2008: http://www.secondegenerazioni.it/2008/09/01/schegge-di-sentimentiincontrollati/0/

${ }^{10}$ Yallaltalia, blog post 17/07/2013: http://www.yallaitalia.it/2013/07/guarda-che-ti-capisco-il-bello-di-essere$\underline{\text { stranieri }}$ 